\title{
Slow Transport Rates of Cytoskeletal Proteins Change During Regeneration of Axotomized Retinal Neurons in Adult Rats
}

\author{
Lisa McKerracher, Manuel Vidal-Sanz, and Albert J. Aguayo \\ Center for Research in Neuroscience, Montreal General Hospital and McGill University, Montreal, Quebec, Canada H3G \\ $1 \mathrm{~A} 4$
}

To investigate cytoskeletal changes associated with axonal regrowth from damaged nerve cells in the mammalian CNS, we examined the slow transport of axonal proteins during the regeneration of adult rat retinal ganglion cell (RGC) axons. Although normally such RGC axons do not regrow after injury in the CNS, they can extend several centimeters when their nonneuronal environment is changed by replacing the optic nerve (ON) with a grafted segment of peripheral nerve (PN). Proteins transported in axons of RGCs from intact control and $\mathrm{PN}$-grafted animals were labeled by an intraocular injection of ${ }^{35}$ S-methionine and examined 4-60 days later by SDS PAGE. During RGC regeneration into PN grafts, the transport rate of tubulin and neurofilament increased twofold, whereas that of actin decreased to nearly one third of its normal rate. Thus, in these regenerating RGC axons, all three major cytoskeletal proteins were largely transported within a single rate component rather than in the two separate components ( $\mathrm{SCa}$ and $\mathrm{SCb}$ ) normally observed in the intact $O N$. Furthermore, the $200 \mathrm{kDa}$ neurofilament protein (NF-H) was persistently detected in Western blots during periods of active regeneration, a finding that contrasts with the late appearance of the NF-H during the developmental growth of retinal axons.

The changes in slow transport observed during RGC regeneration in adult rats may reflect growth-associated responses of mature CNS neurons during periods of active axonal extension.

Ncuronal cytoskclctal protcins move along axons in the slow phase of axoplasmic transport (Lorenz and Willard, 1978; Lasek et al., 1984). Whereas in undamaged mature nerves, this transport is involved in the constant renewal of the cytoskeleton, it is not well known how axotomized neurons regulate the restoration of the cytoplasmic matrix of their damaged axons. The study of the changes in slow axoplasmic transport that accompany axonal regrowth may help define intrinsic neuronal mechanisms that influence peripheral and CNS repair.

In adult mammalian optic nerves, the transport of cytoskeletal

Received May 25, 1989; revised Aug. 4, 1989; accepted Aug. 10, 1989.

We thank Dr. M. Mushynski, Department of Biochemistry, McGill University, for the anti-neurofilament polyclonal antibody, Charles Essagian and Jane Trecarten for technical assistance, and Robert Rush, Paul Jones, and Adrian Pini for their helpful discussions. This work was supported by MRC post-doctoral fellowships to L.M. and M.V.-S., the Luis Manual Foundation grant to M.V.-S., and grants from the Medical Research Council of Canada, the Spinal Cord Research Foundation (USA), and the Multiple Sclerosis Society of Canada to A.J.A.

Correspondence should be addressed to Dr. L. McKerracher, Center for Research in Neuroscience, Montreal General Hospital Research Institute, 1650 Cedar Ave., Montreal, Quebec, Canada H3G 1A4.

Copyright (c) 1990 Society for Neuroscience $0270-6474 / 90 / 100641-08 \$ 02.00 / 0$ proteins has been subdivided into two different rate components (Lorenz and Willard, 1978; Black and Lasek, 1979; Levine and Willard, 1980). The slow component $a$ (SCa) [also called rate V (Lorenz and Willard, 1978)] is composed mainly of tubulin, spectrin, and the three neurofilament subunits whose apparent molecular weights are $200 \mathrm{kDa}(\mathrm{NF}-\mathrm{H}), 150 \mathrm{kDa}(\mathrm{NF}-\mathrm{M})$, and $68 \mathrm{kDa}(\mathrm{NF}-\mathrm{L})$. Slow component $b(\mathrm{SCb})$ (rate IV) includes many different proteins, such as actin, clathrin, spectrin, and calmodulin, and also soluble enzymes (Lorenz and Willard, 1978; Black and Lasek, 1979; McQuarrie et al., 1986).

The composition and transport velocities of the SCa and SCb proteins vary with differences in age, species, and type and state of the neuron: (1) Whereas in CNS axons of the mammalian optic nerve (ON), the SCa and the SCb proteins move in two clearly separated waves, in peripheral nerves (PNs), the rate components of SCa and SCb tend to overlap (Mori et al., 1979; McQuarrie et al., 1986; Oblinger et al., 1987). (2) In peripheral nerves tubulin is found in both $\mathrm{SCa}$ and $\mathrm{SCb}$, but in retinal ganglion cell ( $\mathrm{RGC}$ ) axons, it is transported exclusively in SCa (Tashiro et al., 1984; McQuarrie et al., 1986). The regeneration of $\mathrm{PN}$ axons is accompanied by an acceleration in the rate of $\mathrm{SCb}$ transport and an increase in the amount of tubulin migrating with the SCb proteins (Hoffman and Lasek, 1980; Hoffman et al., 1985). (3) In the developing ON of mammals, the $\mathrm{SCa}$ and $\mathrm{SCb}$ rates are not clearly separated, and the rates of both are increased over those in the adult (Willard and Simon, 1983). (4) In the ON of goldfish, tubulin is also present in the $\mathrm{SCa}$ and SCb (Grafstein, 1986). Furthermore, in these animals, whose RGC axons regrow spontaneously after injury, the rate of slow transport and the amount of tubulin in $\mathrm{SCb}$ increase during regeneration (Grafstein, 1986).

Although information has been gathered on the changes in slow transport that accompany the regeneration of CNS axons in the ON of anamniots, such as goldfish, and in the peripheral nerves of mammals, the failure of axonal regrowth after axotomy of mammalian RGCs and other CNS neurons has precluded similar studies in the CNS of adult mammals.

Recent experiments in rodents indicate that axons of CNS neurons in the retina and other regions of the brain and spinal cord are capable of extensive elongation when their central glial environment is replaced by nonneuronal components of the peripheral nervous system contained in PN grafts (David and Aguayo, 1981; So and Aguayo, 1985, reviewed by Aguayo et al., 1986). Using PN grafts as substitutes of the ON (Vidal-Sanz et al., 1987), we have now examined the slow axonal transport of proteins in regenerating $\mathrm{RGC}$ axons of rats to investigate cytoskeletal changes during the regrowth of severed CNS axons of adult mammals. 
A

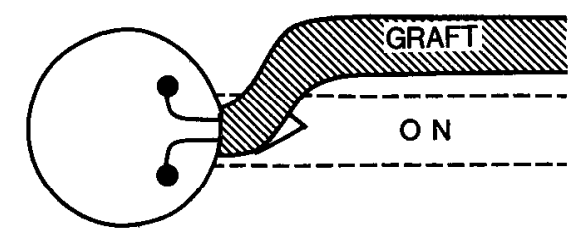

B
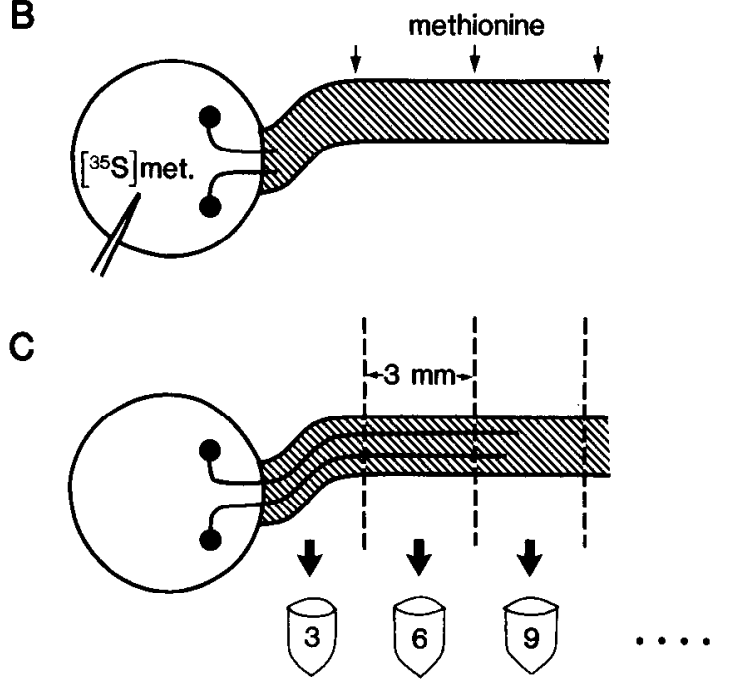

Figure 1 . Schematic illustration of the methods used to study slow transport in regenerating rat $\mathrm{RGC}$ axons. $A$, The left optic nerve $(\mathrm{ON})$ was transected immediately behind the globe and replaced with a peripheral nerve graft. $B$, Seven days later, $500 \mu \mathrm{Ci}{ }^{35} \mathrm{~S}$-methionine was injected into the vitreous chamber of the eye, and unlabeled methionine was applied to the graft. $C$, Seven to sixty days after isotope injection, the graft was removed and cut into consecutive $3-\mathrm{mm}$ segments, and each sample was prepared for SDS PAGE.

\section{Materials and Methods}

Surgical procedures. Female Sprague-Dawley rats weighing 190-220 gm were anesthetized with chloral hydrate $(0.42 \mathrm{mg} / \mathrm{gm}$ body weight, intraperitoneally). In the PN-grafted animals, the left $O N$ was exposed and transected behind the globe, and a $3-\mathrm{cm}$ segment of autologous common peroneal nerve was sutured to the ocular stump of the ON (Vidal-Sanz et al., 1987). The remaining portion of the PN graft was placed under the scalp in a bony groove drilled rostrocaudally along the skull.

Retinal ganglion cell labeling. Seven days after the operation, the animals were reanesthetized, and $500 \mu \mathrm{Ci}$ of ${ }^{35} \mathrm{~S}$-methionine $\left(85 \%{ }^{35} \mathrm{~S}\right.$ methionine, $15 \%{ }^{35} \mathrm{~S}$-cysteine, sp. act. $1200 \mathrm{Ci} / \mathrm{mmol}$, ICN, Irvine, CA) in $5 \mu \mathrm{l}$ saline was injected into the vitreous chamber of the left, PNgrafted eye. At the same time, the PN graft was exposed, and Gelfoam (Upjohn, Don Mills, Ont.) soaked in $250 \mathrm{~mm}$ unlabeled methionine (ICN, Irvine, CA) was placed on the graft to reduce nonspecific labeling of nonneuronal cells (Fig. 1). From 7 to $60 \mathrm{~d}$ after label injection, the animals were killed by an overdose of chloral hydrate and a rapid intracardial saline perfusion. The grafts were removed, desheathed, cut into consecutive $3-\mathrm{mm}$ segments (Fig. 1), and stored at $-80^{\circ} \mathrm{C}$. Nonoperated animals were injected intraocularly with $250-500 \mu \mathrm{Ci}{ }^{35} \mathrm{~S}$ methionine, and the optic nerves and optic tracts also were cut into $3-\mathrm{mm}$ segments and stored as above.

Controls for nonspecific labeling. Because most RGC die when the ON is transected near the cyc (Villegas-Pérez ct al., 1988) and only a small number of axons regenerate into PN grafts anastomosed to the ocular stump (Vidal-Sanz et al., 1987), technical difficulties were anticipated in the distinction of axonally transported labeled proteins and nonspecific labeling. Thus, several experiments were carried out to differentiate proteins transported along regenerating RGC axons from proteins originating from nonneuronal components of the PN graft: (1)
Radiolabeled blood-borne proteins incorporated in the graft were investigated by injecting $500 \mu \mathrm{Ci}{ }^{35} \mathrm{~S}$-methionine into the femoral vein of the PN-grafted animals. (2) Proteins synthesized by nonneuronal cells in the graft were examined in two ways: (a) the PN grafts were injected in vivo with $500 \mu \mathrm{Ci}{ }^{35} \mathrm{~S}$-methionine, or (b) the grafts were incubated for $3 \mathrm{hr}$ in vitro in methionine-free RPMI 1640 (Gibco Labs., Grand Island, $\mathrm{NY}$ ) with $100 \mu \mathrm{Ci}{ }^{35} \mathrm{~S}$-methionine. (3) The radioactive labeling of nonneuronal tissues in the PN grafts caused by direct diffusion of the label from the eye was investigated in PN segments placed loosely in the orbit and prevented from becoming innervated by RGC axons. For this purpose, the PN segments were not attached to the ocular stump of the transected $\mathrm{ON}$, the eye was injected $7 \mathrm{~d}$ later, and the nerve segments were processed as described for those innervated by RGC axons, except that cold methionine was not applied to the graft. (4) Finally, the possibility that $O N$ transection and PN grafting could result in a substantial leakage of the radiolabel from the eye into the circulation was investigated by comparing in the normal and the PN-grafted rats the radioactivity in the contralateral, uninjected eye to that of the injected eye. The retinae were homogenized in $500 \mu \mathrm{l}$ electrophoretic sample buffer, and proteins were precipitated in trichloroacetic acid (Schaffner and Weissmann, 1973) and counted using Scintiverse (Fisher, Montreal, Canada).

$S D S$ gel electrophoresis and densitometry. Frozen PN or ON segments were homogenized in $30 \mu \mathrm{l}$ of electrophoretic sample buffer per millimeter of tissue using a motorized Teflon-in-glass homogenizer. The samples were boiled, then centrifuged for $15 \mathrm{~min}$ at $14,000 \times \mathrm{g}$ before electrophoretic separation (Laemmli, 1970). The gels were stained with Coomassie blue, impregnated with Enhance (NEN, Boston, MA) or $20 \%$ PPO (NEN) in glacial acetic acid, then dried and exposed to Kodak $\mathrm{X}$-Omat AR film, which was preflashed to 0.2 OD (Laskey and Mills, 1975).

Autoradiographs were scanned with an LKB Ultrascan laser densitometer and analyzed using Gelscan XL software (LKB, Broma, Sweden) to determine the areas under the tubulin, actin, and serum albumin peaks.

Measurement of transport rates. For both normal and PN-grafted ONs, the distance of the front of the axonally transported proteins was plotted against time, and the transport rate was calculated from the slope (see Fig. 7). Differences between the slopes were compared by an analysis of covariance. The transport front was determined visually on the fluorographs of normal $O N$ and tracts. With sufficient exposure time, the front was independent of the duration of exposure. During regeneration, the transport front of tubulin and actin was determined by a quantitative comparison of their levels relative to serum albumin (cf. Fig. 6) which is a labeled, nontransported protein. The gels were scanned with a densitometer and the ratios of tubulin/serum albumin and actin/ serum albumin were determined for each lane. In noninnervated control animals, the average ratio was 1 (see Fig. $6 A$ ). In experimental control animals, the distance from the eye where the ratio fell to 1 was taken to be the transport front (Fig. 6, $B, C$ ). This point matched the visually detected front (Fig. 5).

Immunoblotting. The primary antibodies used were SM 31 (Sternberger-Meyer), which recognizes the phosphorylated NF-H epitope, and an antineurofilament affinity purified polyclonal antibody, which reacts mainly with NF-M and slightly with NF-H. The secondary antibody was an alkaline phosphatase-labeled antimouse (Promega, Madison, WI) for SM31 and ${ }^{125}$-I protein A (NEN) for the antineurofilament polyclonal antibody. Following electrophoretic separation, proteins were transferred to nitrocellulose at $450 \mathrm{~mA}$ for $3 \mathrm{hr}$ in $12.5 \mathrm{~mm}$ Tris, 96 glycine $\mathrm{pH} 8.1$, with $0.01 \%$ SDS. The blots were then processed as described (Schoenfeld et al., 1989). Intermediate filaments used as neurofilament standards were prepared according to Chiu and Norton (1982).

\section{Results}

\section{Slow axonal transport in normal adult rats}

In normal adult rat $\mathrm{ON}$, the main proteins migrating in the two components of slow transport have been identified and characterized previously (McQuarrie et al., 1986). In agreement with such observations, we have found that tubulin and the three neurofilament subunits are the most abundantly labeled SCa proteins. Furthermore, in the intact $\mathrm{ON}$, these proteins are transported exclusively within the SCa (Fig. 2). Although actin is considered primarily a SCb protein (McQuarrie et al., 1986), 
A. 8 days

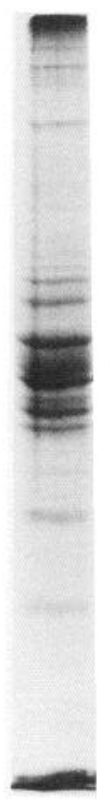

C

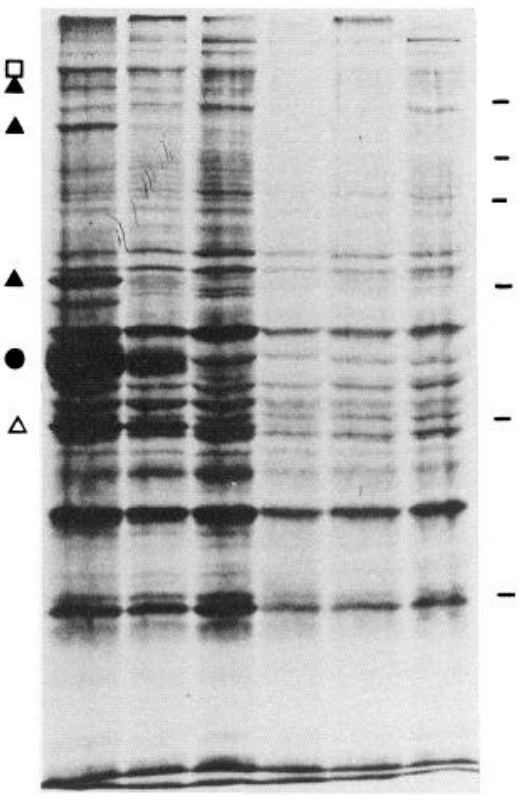

$\begin{array}{llllll}3 & 6 & 9 & 12 & 15 & 18\end{array}$
B. 21 days

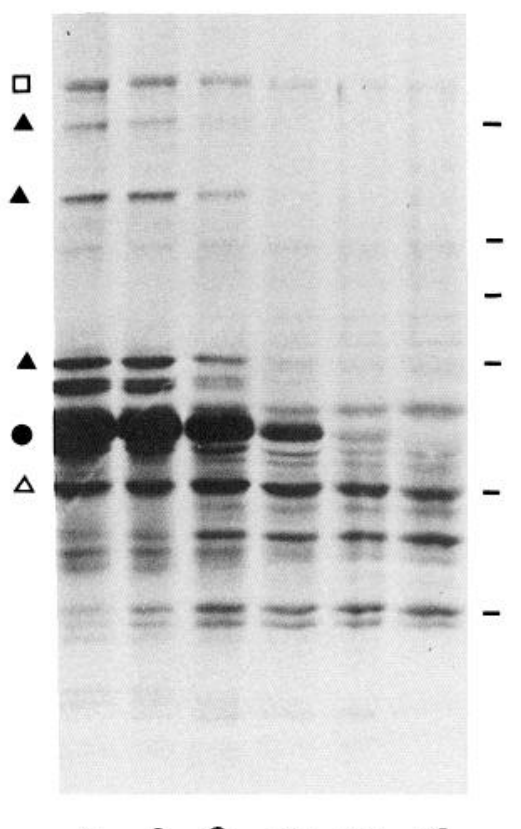

$\begin{array}{llllll}3 & 6 & 9 & 12 & 15 & 18\end{array}$
C. 46 days

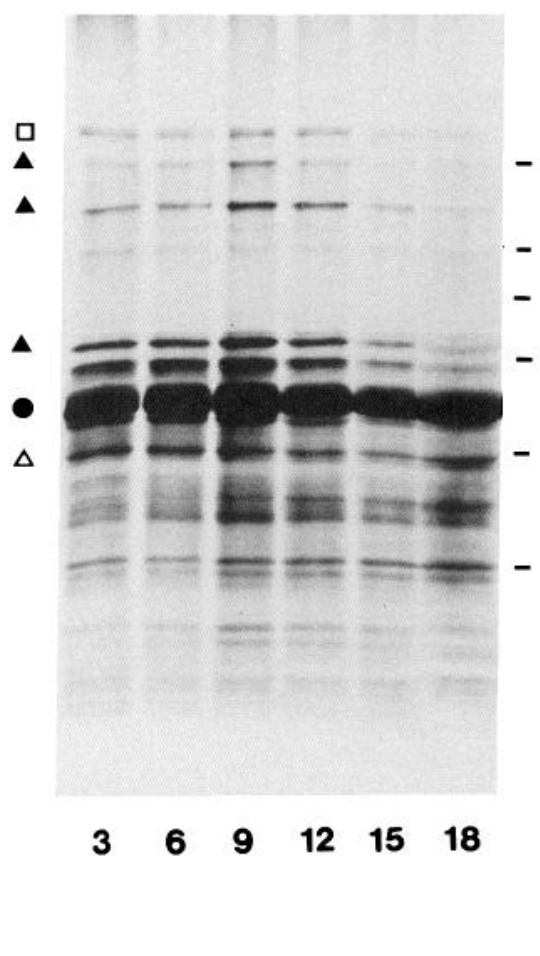

Figure 2. Fluorographs of ${ }^{35} \mathrm{~S}$-methionine-labeled protein from normal animals. Consecutive 3-mm segments of the optic nerve and optic tract from animals examined $8 \mathrm{~d}(A), 21 \mathrm{~d}(B)$, and $46 \mathrm{~d}(C)$ after isotope injection. A photograph of Coomassie blue staining $(C)$ of the first segment of the 8-d animal is shown in $A$, and it is typical of the Coomassie blue staining of all of the samples from normal animals. The SCb proteins, including actin (open triangles) and spectrin (open squares), are most heavily labeled at $9 \mathrm{~mm}$ from the eye at $8 \mathrm{~d}$. The gradual progress of the SCa proteins, identified by tubulin (closed circles) and the neurofilament polypeptides (closed triangles), is seen at increasing times after injection. The positions of the $M_{\mathrm{r}}$ standards $(200,116,92,66,45,30, \mathrm{kDa})$ are indicated by the bars on the right side of each gel. The acrylamide concentration of $A$ was $9 \% . B$ and $C$ were $5-14 \%$ gradient gels. Exposure times were $0.5,1$, and $4 \mathrm{~d}$, respectively.

some actin also was identified in the SCa (Fig. 2). Spectrin was found in both $\mathrm{SCa}$ and $\mathrm{SCb}$.

The front of SCa moved at a rate of $0.5 \mathrm{~mm} / \mathrm{d}$ (correlation coefficient 0.9 ), and the front of SCb migrated at $2.7 \mathrm{~mm} / \mathrm{d}$ (correlation coefficient 0.8 ; see Fig. 7). Most of the proteins that comprised $\mathrm{SCb}$ were only evident at early postinjection times because they travelled along the $\mathrm{ON}$ and tract without leaving a trail of label (Fig. 2). However, 46 (Fig. 2C) and 60 days (not shown) after labeling, the longest time points examined in this study, there were still labeled SCa proteins in the most proximal segments of the ON (cf. Fig. $2 C$ for a $46 \mathrm{~d}$ time point).

\section{Sources of nonspecific labeling of PN grafts}

Previous studies in this laboratory have estimated that an average of 3600 RGC axons (range 949-12,385) regrow into PN grafts joined to the cut ON. This population of regenerated RGC axons represents approximately $3 \%$ of the RGC axons present in the intact ON of rats (Vidal-Sanz et al., 1987). Such reduction in the number of RGC axons made it necessary to carefully discriminate the axonally transported proteins from spurious labeling of graft components (see Materials and Methods).

It was found that blood-borne radioactivity resulted in the labeling of a protein of $M_{\mathrm{r}} 66 \mathrm{kDa}$ contained within the graft (Fig. 3). This protein was the major Coomassie blue-stained protein in all the PN grafts. Although the level of labeling of this polypeptide differed in each animal, the labeling was uniform along a given graft (Fig. $3 B$ ). This nonspecifically labeled protein was probably serum albumin, and we refer to it as such in this paper.

The non-neuronal cells of the graft synthesized a large number of proteins, including tubulin and actin. Neurofilaments are not present in non-neuronal cells (see Fig. 4), and there were no proteins synthesized by the non-neuronal which comigrated with NF-M cells (Fig. 3A).

Diffusion of the label after intraocular injection resulted in the labeling of serum albumin, tubulin, and actin in the PN grafts that were prevented from innervation by RGC axons (Fig. $3 B$ ). Again, proteins with the same apparent molecular weight as NF-M were not observed under such conditions.

Transection of the ON near the globe did not affect the amount of label that diffused from the eye. In grafted animals, the labeling of the contralateral retina was $7 \%(n=15$ animals) of that in the retina of the injected eye. A similar labeling index $(6 \%)$ was found in the intact rats used as controls ( $n=8$ animals) following the labeling of one eye.

Thus, although there was nonspecific labeling of non-neuronal tissues, we could distinguish such spurious labeling from that of the proteins transported in the relatively small population of RGC axons that had regenerated along the PN grafts. 
A

Figure 3. Fluorographs showing control experiments. A, Labeling following intraocular injection is compared to nonspecific labeling. Lane 1 , SCa proteins of normal animals after intraocular injection. Lane 2, Slowly transported proteins from a PN-grafted animal after intraocular injection and application of unlabeled methionine to the graft as illustrated in Figure 1. Lane 3, Labeling in a graft 11 days after injection into the femoral vein to label the blood supply. Lane 4, Labeling of a peroneal nerve after a 3-hr in vitro incubation. Lane 5, Proteins labeled in a graft $11 \mathrm{~d}$ after directly injecting the isotope into the graft. Acrylamide was $5-14 \%$. Lanes $1-3$ were exposed 3 months. Lanes 4 and 5 are from the same gel but were exposed 3 weeks. $B$, Consecutive $3-\mathrm{mm}$ segments of a noninnervated graft that was not linked to the eye. The graft was processed 10 days after intraocular injection; $5-14 \%$ acrylamide, 1.5 -month exposure. Bars indicate the $M_{\mathrm{r}}$ of standards $(200,116$, $96,66,45,30$ ). Tubulin (closed circles), neurofilaments (closed triangles), actin (open triangles), spectrin (open squares), and serum albumin (open circles) polypeptides are labeled.

A.

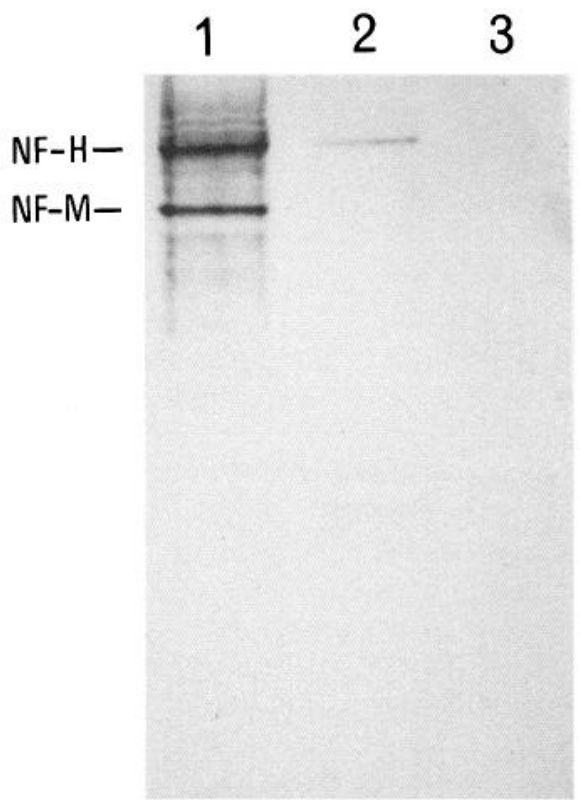

B.

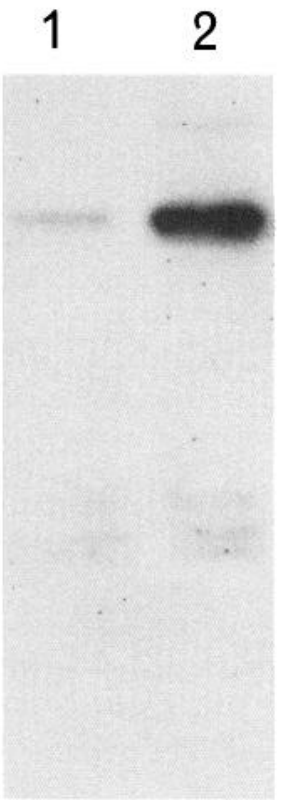

Figure 4. Immunoblot analysis of neurofilament reactivity in $\mathrm{PN}$ grafts. The proteins were electrophoretically separated and transferred to nitrocellulose before reacting with monoclonal SM 31, which labels phosphorylated neurofilaments $(A)$ or a polyclonal antineurofilament antibody $(B)$. A, Lane 1, SM 31 reactivity of spinal cord neurofilament proteins. Lane 2, An 18-d PN graft innervated with regenerating RGC axons. Lane 3, A noninnervated 18-d PN graft. In lanes 2 and 3, $50 \mu \mathrm{g}$ protein were loaded. $B$, Lane 1 , The antineurofilament reactivity to an 18-d PN graft. Lane 2, Normal optic nerve.
B

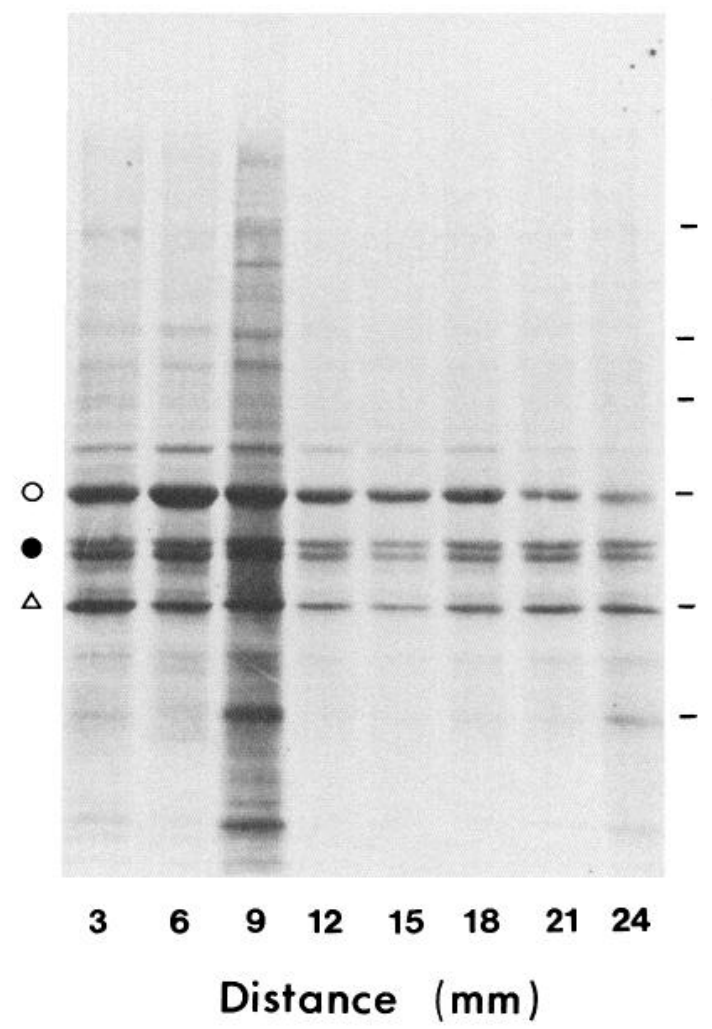

\section{Identification of transported neurofilament proteins in peripheral nerve grafts}

The regenerating RGCs were labeled by an intraocular injection given $7 \mathrm{~d}$ after grafting, a time when previous anatomical studies have shown that the RGC axons have begun to extend into the PN grafts (unpublished observations). Because the neurofilament proteins are not present in the non-neuronal cells of the PN graft, they were used as indicators of axonally transported proteins (Fig. 4). To identify the three neurofilament subunits transported along RGC axons in the PN grafts, we (1) compared the electrophoretic mobility of transported proteins in the PN grafts with neurofilament proteins transported into the intact ON (Fig. $3 A$ ) or with purified NF (not shown) and (2) used immunoblotting. Although the identification of NF-H in the fluorographs obtained from the grafts was obscured by the numerous bands found in the $200 \mathrm{kD}$ region, some of which corresponded to non-neuronal proteins (Fig. 3), the presence of $\mathrm{NF}-\mathrm{H}$ was detected by immunoblotting.

When noninnervated PN grafts were examined, no NF immunoreactivity was observed (Fig. 4). On the other hand, NF-H immunoreactivity was detected in the PN grafts innervated by regenerated RGC axons $17 \mathrm{~d}$ and $28 \mathrm{~d}$ after grafting (Fig. 4). These findings confirmed that NF-H expression correlated with RGC growth into the PN grafts. Although NF-H was detected in Western blots by SM 31, an antibody that recognizes a phosphorylated epitope, the proteins in the $200 \mathrm{kDa}$ region of the fluorographs were very light, suggesting that the amount of NF-H is reduced relative to NF-M in regenerating $\mathrm{RGC}$.

NF-M was the most clearly labeled NF protein in the fluorographs. This NF was identified in both PN grafts and ONs 11 
A.11 days

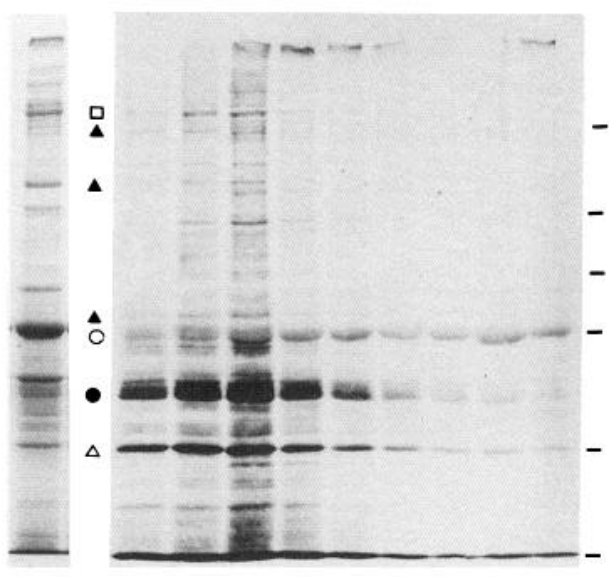

C $\begin{array}{lllllllll}3 & 6 & 9 & 12 & 15 & 18 & 21 & 24 & 27\end{array}$

Distance $(\mathrm{mm})$

\section{B. 21 days}

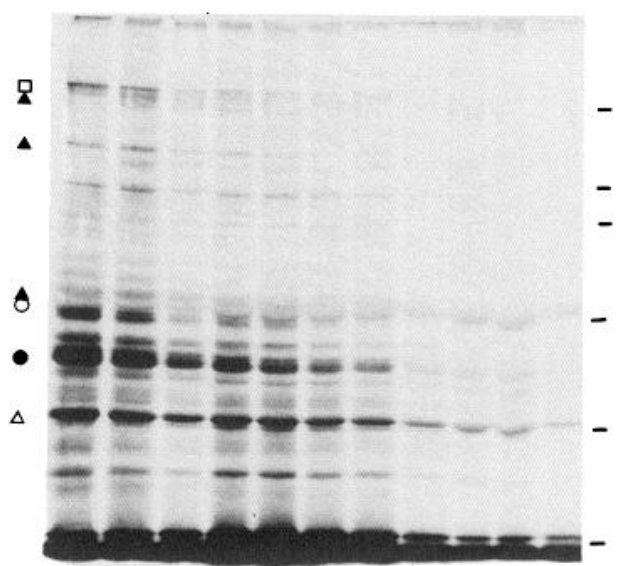

$\begin{array}{lllllllllll}3 & 6 & 9 & 12 & 15 & 18 & 21 & 24 & 27 & 30 & 33\end{array}$

Distance $(\mathrm{mm})$

\section{46 days}

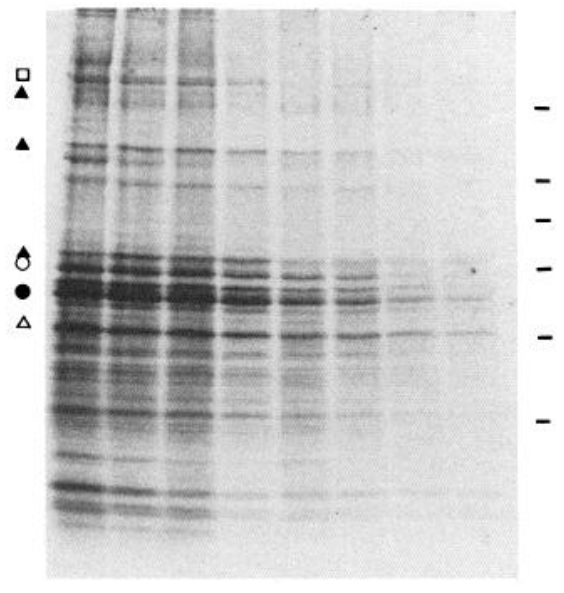

$\begin{array}{llllllll}3 & 6 & 9 & 12 & 15 & 18 & 21 & 24\end{array}$

Distance $(\mathrm{mm})$
Figure 5. Fluorographs of labeled proteins from grafted animals. The animals were labeled as illustrated in Figure 1 and examined $11(A), 21(B)$, and 46 (C) d later. Symbols label identified proteins as described in the legend to Figure 3. Lane $C$ in $A$ shows Coomassie blue staining of a lane from the gel shown in $A$. The neurofilaments were identified by their comigration with purified neurofilaments. The acrylamide concentrations used were $7.5 \%, 7.5 \%$, and $5-14 \%$, and exposure times were 1,3 , and 3 months, respectively. $\mathrm{d}$ after the intraocular injection of the tracer (Fig. 3A). The presence of NF-M in the PN grafts that were innervated by the regenerating RGC axons was confirmed also by immunoblots (Fig. 4).

In contrast to the normal ON and tract, the NF-L was not clearly visible on the fluorographs of reinnervated PN grafts. Although the nonradioactive serum albumin distorted the bands in this region of the gel (Fig. 5), it would appear that in regenerating RGC axons, the amount of NF-L may be reduced in relation to that of NF-M.

\section{Tubulin and actin transport during $R G C$ regeneration}

Although the total amount of tubulin and actin visualized by Coomassie blue staining was constant along the length of the PN graft, that of radioactive tubulin and actin was much greater in the proximal segments of the PN graft (Fig. 5). To identify the axonally transported tubulin and actin, we used densitometry to compare these proteins in PN grafts containing regenerating RGC axons (Fig. 5) with those in the noninnervated grafts (Fig. $3 B$ ). In the RGC-innervated PN grafts, the amounts of tubulin and actin were compared with that of a nonaxonally transported protein, serum albumin (see above). In the control noninnervated PN grafts, the tubulin/serum albumin and actin/ serum albumin ratios were similar along the entire length of the PN graft (Fig. 6A). Their values ranged from 0.5 to 1.5 , with an average of 1.0 ( $n=3$ animals). In contrast, in the PN-grafted animals, the ratios of tubulin/serum albumin and actin/serum albumin were high proximally, near the eye (an average high value of 3.2 for tubulin/serum albumin and 2.8 for actin/serum albumin) ( $n=28$ animals) and decreased distally to control levels (Fig. 6, $B-D$ ). Ratios greater than 1.0 were interpreted as an indication of the specific labeling of tubulin and actin. There- 


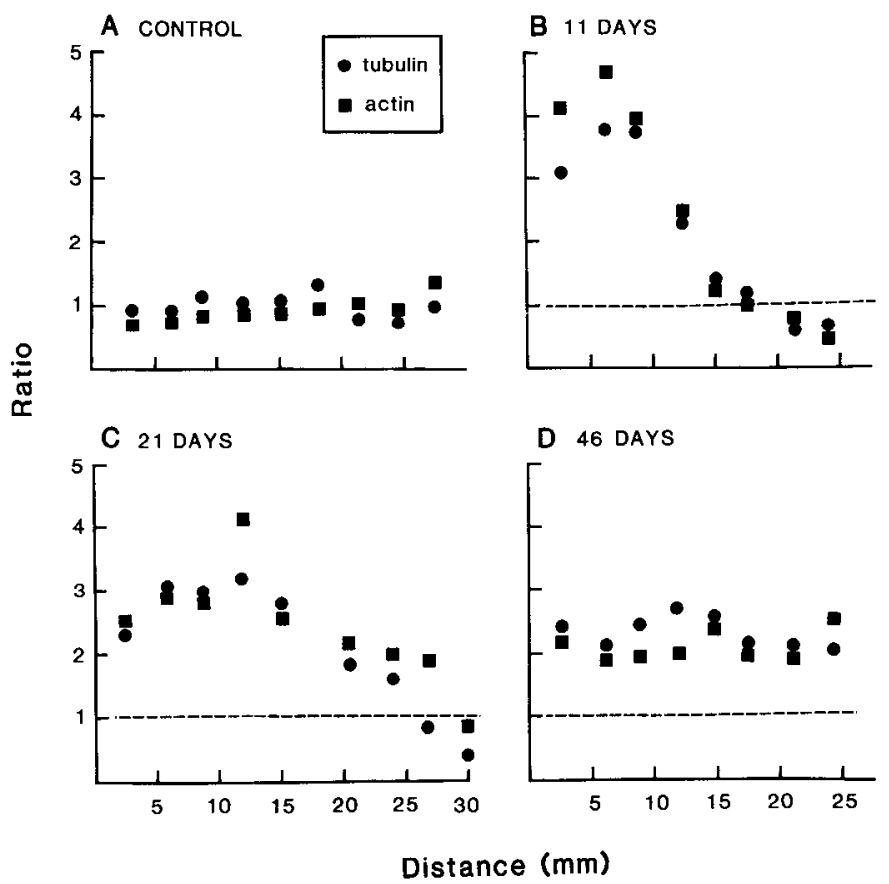

Figure 6. Quantitative comparison of tubulin and actin labeling relative to a nontransported protein, serum albumin. The ratios of actin/ serum albumin (squares) and tubulin/serum albumin (circles) were determined from densitometric scans of the fluorographs and representative samples are shown. $A$, Tubulin and actin labeling from a control animal similar to that of Figure $3 B$. The labeling is similar along the entire length of the graft and represents nonspecific labeling. $B-D, \mathrm{PN}$ grafted animals examined $11(B), 21(C)$, and $46(D) \mathrm{d}$ after isotope injection. The ratios are high proximally and fall to control levels at early time points, but by $46 \mathrm{~d}$ after labcling, the ratios do not fall to background levels.

fore, the fronts of labeled protein transported along the PN graft were estimated from the sites where the ratios dropped below 1 (Fig. 7).

\section{Rate of slow transport during $R G C$ regeneration}

The migration of tubulin, actin, and neurofilament proteins along the $\mathrm{PN}$ graft proceeded further distally with longer postinjection times (Fig. 5). At $7 \mathrm{~d}$ there was only proximal labeling ( 2 animals), at $11 \mathrm{~d}$ ( $n=6$ animals) the labeling had progressed to the middle of the PN graft, and by $21 \mathrm{~d}$ ( $n=14$ animals) it had neared the end of the PN graft. Labeled proteins were detected at the distal end of the PN graft by $30 \mathrm{~d}$ in 2 of 4 animals, by $46 \mathrm{~d}$ in 3 of 4 animals, and by $60 \mathrm{~d}$ in 1 of 2 rats. At longer time points, the proximal labeling remained high, as in the normal ON and tract (Fig. 5), but the labeling at the distal end did not decrease to the average background level (Fig. 6). No-

Table 1. Transport rates ${ }^{a}$ in normal and regenerating RGCs

\begin{tabular}{lll} 
Cytoskeletal protein & $\begin{array}{l}\text { Optic nerve } \\
\text { and tract }\end{array}$ & $\begin{array}{l}\text { Regenerating } \\
\text { RGC }\end{array}$ \\
\hline Tubulin & 0.5 & 1.0 \\
Neurofilaments & 0.5 & 1.0 \\
Actin & 2.7 & 1.0
\end{tabular}

${ }^{a}$ Rates were taken from the slope of distance-on-time graphs (Fig. 7) and are expressed as millimeters per day. Correlation coefficients are given in the text.

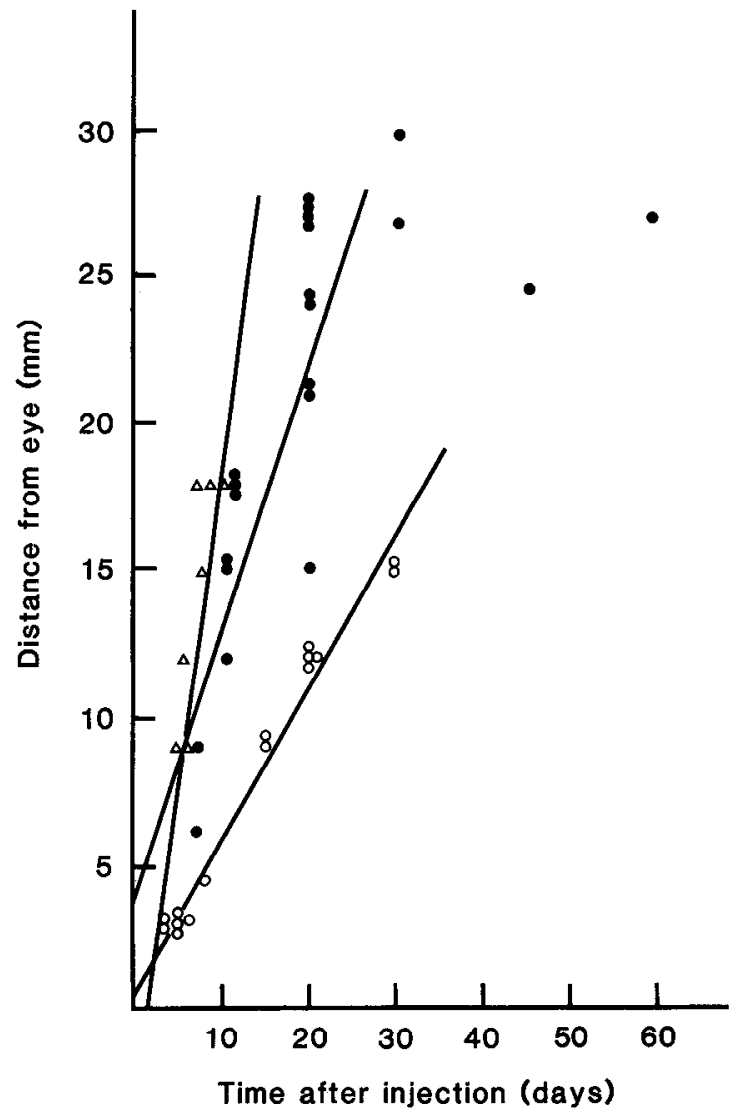

Figure 7. Regressions of distance-on-time for slow transport in normal $\mathrm{RGC}$ axons and regenerating $\mathrm{RGC}$ axons. The fronts of $\mathrm{SCa}$ (open circles) and $\mathrm{SCb}$ (open triangles) from normal animals were determined from the furthest distance from the eye where tubulin and neurofilament protein, and actin, respectively, were located. In regenerating RGC (closed circles), quantitative analysis of the specific tubulin and actin labeling relative to serum albumin (see Fig. 6) was used to determine the transport front, using 1.0 as the cutoff for specific labeling. The regression line for points from regenerating animals was calculated omitting time points after $21 \mathrm{~d}$ because the graph was not linear after that point. The regression lines were not constrained to pass through the origin. The three population regression lines have significant differences between slopes, $p \leq 0.05$.

tably, the tubulin, actin, and neurofilament labeling appeared to follow a very similar time course in all animals (Figs. 5, 6).

The slow transport fronts were calculated for each animal from graphs similar to those in Figure 6. The average transport rate was determined from regressions of distance-on-time (Fig. 7), and the results are shown in Table 1. The rate of slow transport during regeneration was $1.0 \mathrm{~mm} /$ day (correlation coefficient 0.8 ), a value that falls between the $\mathrm{SCa}$ and $\mathrm{SCb}$ rates in normal nerves (Fig. 7). When the rate of slow transport was calculated for the regenerating $\mathrm{RGC}$ axons of individual rats, the rates ranged from 0.5 to $1.6 \mathrm{~mm} / \mathrm{d}(n=18$ animals).

\section{Discussion}

Detection of slow transport in $R G C$ axons regenerating into PN grafts

The rat $O N$ was selected for this study of changes in the transport of cytoskeletal proteins during axonal regrowth from the CNS of adult mammals because both the normal slow axonal transport in the ON (Black and Lasek, 1979; Levine and Willard, 
1980; Nixon and Logvinenko, 1986) and the anatomical regeneration of RGC axons (So and Aguayo, 1985; Vidal-Sanz el al., 1987; Villegas-Pérez et al., 1988) have been investigated previously. The study of the proteins transported in RGC axons regenerating along $\mathrm{PN}$ grafts that replace $\mathrm{ONs}$ is, however, hampered by (1) the relatively small population of RGC axons that regenerate into the grafts (Vidal-Sanz et al., 1987), (2) the need for a long exposure time of the fluorographs, and (3) the labeling of nonneuronal proteins residing within the graft itself.

Nonetheless, we were able to distinguish the transported proteins from spurious labcling by several control experiments, including a comparison of innervated and noninnervated grafts (Fig. 3). We found that the transport characteristics of the cytoskeletal proteins change when RGC axons regenerate.

\section{Neurofilament transport during regeneration}

The rate of neurofilament transport in rat injured RGC axons increased approximately 2 -fold during regeneration. This change in NF transport resembles that described previously in the newborn rabbit $\mathrm{ON}$ and in other developing neuronal projections in mammals (Hoffman et al., 1983; Willard and Simon, 1983). The rate of NF transport is also known to increase in regenerating axons of the adult rat sciatic nerve (Hoffman and Lasek, 1980; Hoffman et al., 1985; McQuarrie and Lasek, 1989). Since the function of neurofilament transport in axons is unclear, we do not know why their rate of transport increases. A possible cxplanation is that this change reflects the increase in the rate of tubulin transport. Because NFs are crosslinked to microtubules (Hirokawa et al., 1984), NFs could be passively cotransported with the microtubules (see below).

The presence of NF-H in the regenerating RGC axons of these rats is also of interest because, in the developing $O N$ of the rat and other mammals, the NF-H is not detected at early postnatal limes (Willard and Simon, 1983; Pachter and Liem, 1984) when axons are elongating and the neurofilament transport rate is increased (Willard and Simon, 1983). In such animals, the NF-H is first detected at a time when the rate of NF transport decreases toward adult values. Although transport rates have not been estimated in newborn rats, the increased rates observed during $\mathrm{RGC}$ regeneration may correspond to the intermediate values of postnatal development when the amount of NF-H expressed is small compared to the amount in adult axons. Since NF-H has been implicated in the formation of a stable stationary matrix in axons (Lewis and Nixon, 1988), it may be that the proportion of moving and stationary cytoskeletal components differs between developing nerve and regenerating nerves.

\section{Tubulin transport during regeneration}

The increased rate of tubulin transport documented here during $\mathrm{RGC}$ regeneration in adult rats has been obscrved also when mammalian peripheral nerves (Hoffman and Lasek, 1980; Hoffman et al., 1985) or goldfish ON regenerate following axotomy (Grafstein and Murray, 1969; Grafstein, 1986). In these examples, the proportion of tubulin transported in $\mathrm{SCb}$ also increases. These changes may all reflect complex rearrangements of the cytoskeleton that occur during axonal regrowth.

Experimental evidence suggests that although the $\mathrm{SCa}$ and $\mathrm{SCb}$ tubulin are present as microtubule polymers (Keith, 1987), the tubulin in SCa is different (Denoulet et al., 1989) and more stable than SCb tubulin (Tashiro et al., 1984). In the developing nervous system, the posttranslationally regulated nonstable forms of tubulin predominate (Cumming et al., 1984). Thus, it may be that in rat RGC a modification of tubulin to the less stable $\mathrm{SCb}$ form of tubulin accompanics axonal regrowth. In addition, recent experiments have shown that there is an increased expression of a developmentally regulated tubulin gene when peripheral nerves regenerate (Miller et al., 1989). It is tempting to speculate that a newly expressed form of tubulin is less likely to be deposited in the stationary cytoplasmic matrix (Nixon and Logvinenko, 1986; reviewed by Hollenbeck, 1989), allowing a rapid mobilization of the microtubules to the growing end of the axon.

\section{A single slow transport rate during regeneration?}

In normal $\mathrm{ON}$ and tract, tubulin and neurofilaments are transported in $\mathrm{SCa}$, whereas most of the actin moves at a faster rate in SCb (Black and Lasek, 1979; McQuarrie et al., 1986). During the regeneration of rat $\mathrm{RGC}$ axons into $\mathrm{PN}$ grafts, all of the detectable transported actin migrated at the same rate as tubulin and neurofilaments. Although our experiments did not permit a very sensitive detection of transported proteins, our results strongly suggest that most of the tubulin, neurofilament proteins, and actin migrate at the same rate for the following reasons.

First, there is an increase in the synthesis of actin during the regeneration of peripheral nerves (Hoffman and Lasek, 1980; Sinicropi and Mcllwain, 1983; Tetzlaff et al., 1988), suggesting that our failure to detect a separate $\mathrm{SCb}$ actin component is not due to its decreased synthesis. Second, at the earliest time points we examined (14 and $17 \mathrm{~d}$ after PN grafting), the axons have not yet reached the distal end of the approximately $3-\mathrm{cm}$ grafts (Trecarten et al., 1986; unpublished observations). Therefore, an actin front moving ahead of that of the tubulin and neurofilament proteins would have been detected as distal accumulation of actin. Finally, a transported $170 \mathrm{kDa}$ protein was visible in many of our fluorographs (e.g., Figs. 3, 4B) that may correspond to clathrin, a protcin found exclusively in $\mathrm{SCb}$ (Garner and Lasek, 1981). Thus, it seems likely that there is a coordinated transport of $\mathrm{SCa}$ and $\mathrm{SCb}$ proteins when $\mathrm{RGC}$ axons regenerate. These findings from the regenerating rat $\mathrm{RGC}$ are in agreement with the suggestion that the comigration of the $\mathrm{SCa}$ and $\mathrm{SCb}$ polypeptides is a hallmark of neurons that regenerate axons (Cancalon et al., 1988).

The decrease in the rate of actin transport suggests that the microtubule-NF matrix is required for actin transport. It is thought that the rate-limiting process to regeneration is the velocity of $\mathrm{SCb}$ because a correspondence between the rate of $\mathrm{SCb}$ and the axonal growth rate has been observed in regenerating goldfish ONs (Grafstein, 1986) and mammalian peripheral nerves (Hoffman and Lasek, 1980; Wujek and Lasek, 1983; McQuarrie and Lasek, 1989). We also observe a similarity between the rate of slow transport during $\mathrm{RGC}$ regeneration, which we found to avcragc $1.0 \mathrm{~mm} / \mathrm{d}$, and the rate of elongation of $\mathrm{RGC}$ axons previously reported as $1.0 \mathrm{~mm} / \mathrm{d}$ (Trecarten et al., 1986) to 2.0 $\mathrm{mm} / \mathrm{d}$ (Cho and So, 1987). It may be that the rate-limiting step to regeneration is not the rate of $\mathrm{SCb}$, which is a very heterogeneous group of proteins (Lasek et al., 1984), but the overall rate of transport of the cytoskeleton.

\section{Conclusions}

We have reported that the rate of microtubule and neurofilament transport increases during RGC regeneration while that of actin decreases. These rate changes result in the comigration of these three major cytoskeletal proteins, suggesting that they are coordinately transported. Although during RGC regeneration the 
characteristics of slow transport show similarities to those during development (Willard and Simon, 1983), there are differences as well. In particular, NF-H continues to be expressed. Our observations suggest that changes in the structure of the cytoskeleton may be a prerequisite for axonal regrowth after injury because these changes in RGCs are not elicited by injury in the absence of axonal regeneration (McKerracher et al., 1989).

\section{References}

Aguayo, A. J., M. Vidal-Sanz, M. P. Villegas-Perez, S. A. Keirstead, M. Rasminsky, and G. M. Bray (1986) Axonal regrowth and connectivity from neurons in the adult rat retina. In Retinal Signal Systems, Degenerations and Transplants, E. Agardh and B. Ehinger, eds., pp. 257-270, Elsevier, Amsterdam.

Black, M. M., and R. J. Lasek (1979) Axonal transport of actin: Slow component $b$ is the principal source of actin for the axon. Brain Res. 171: 401-413.

Cancalon, P., S. T. Brady, and R. J. Lasek (1988) Slow transport in a nerve with embryonic characteristics, the olfactory nerve. Dev. Brain Rcs. 38: 275-285.

Chiu, F.-C., and W. T. Norton (1982) Bulk preparation of CNS cytoskeleton and the separation of individual neurofilament proteins by gel filtration: Dye-binding characteristics and amino acid compositions. J. Neurochem. 39: 1252-1260.

Cho, E. Y.P., and K.-F. So (1987) Rate of regrowth of damaged retinal ganglion cell axons regenerating in a peripheral nerve graft in adult hamsters. Brain Res. 419: 369-374.

Cumming, R., R. D. Burgoyne, and N. A. Lytton (1984) Immunocytochemical demonstration of $\alpha$-tubulin modification during axonal maturation in the cerebellar cortex. J. Cell Biol. 98: 347-351.

David, S., and A. J. Aguayo (1981) Axonal elongation into peripheral nervous system "bridges" after central nervous system injury in adult rats. Science 214: 931-933.

Denoulet, P., G. Filliatrcau, B. de Nechaud, F. Gros, and L. Di Giamberardino (1989) Differential axonal transport of isotubulins in the motor axons of the rat sciatic nerve. J. Cell Biol. 108: 965-971.

Garner, J. A., and R. J. Lasek (1981) Clathrin is axonally transported as part of slow component b: The microfilament complex. J. Cell Biol. 88: $172-178$

Grafstein, B. (1986) The retina as a regenerating organ. In The Retina, R. Adler and D. Farber, eds., pp. 275-335, Academic, New York.

Grafstein, B., and M. Murray (1969) Transport of protein in goldfish optic nerve during regeneration. Exp. Neurol. 25: 494-508.

Hirokawa, N., M. A. Glicksman, and M. B. Willard (1984) Organization of mammalian neurofilament polypeptides within the neuronal cytoskeleton. J. Cell Biol. 98: 1523-1536.

Hoffman, P. N., and R. J. Lasek (1980) Axonal transport of the cytoskeleton in regencrating motor neurons: Constancy and change. Brain Res. 202: 317-333.

Hoffman, P. N., R. J. Lasek, J. W. Griffin, and D. L. Price (1983) Slowing of the axonal transport of neurofilament proteins during development. J. Neurosci. 3: 1694-1700.

Hoffman, P. N., G. W. Thompson, J. W. Griffin, and D. L. Price (1985) Changes in neurofilament transport coincide temporally with alterations in the caliber of axons in regenerating motor fibers. J. Cell Biol. 101: 1332-1340.

Hollenbeck, P. J. (1989) The transport and assembly of the axonal cytoskeleton. J. Cell Biol. 108: 223-227.

Keith, C. H. (1987) Slow transport of tubulin in the neurites of differentiated PC12 cells. Science 235: 337-339.

Laemmli, U. K. (1970) Cleavage of structural proteins during assembly of the head of bacteriophage T4. Nature 227:680-685.

Lasek, R. J., J. A. Garner, and S. T. Brady (1984) Axonal transport of the cytoplasmic matrix. J. Cell Biol. 99: 212s-221s.

Laskey, R. A., and A. D. Mills (1975) Quantitative film detection of ${ }^{3} \mathrm{H}$ and ${ }^{14} \mathrm{C}$ in polyacrylamide gels by fluorography. Eur. J. Biochem. 56: 335-341.

Levine, J., and M. Willard (1980) The composition and organization of axonally transported proteins in the retinal ganglion cells of the guinea pig. Brain Res. 194: 137-154.
Lewis, S. E., and R. A. Nixon (1988) Multiple phosphorylated variants of the high molecular mass subunit of neurofilaments in axons of retinal cell neurons: Characterization and evidence for their differential association with stationary and moving neurofilaments. J. Cell Biol. 107: 2689-2701.

Lorenz, T., and M. Willard (1978) Subcellular fractionation of intraaxonally transported polypeptides in the rabbit visual system. Proc. Natl. Acad. Sci. USA 75: 505-509.

McKerracher, L., M. Vidal-Sanz, C. Essagian, and A. J. Aguayo (1989) Changes in the rate of slow transport after axotomy and during the regeneration of adult rat retinal ganglion cell axons. Soc. Neurosci. Abstr. 15: 157.

McQuarrie, I. G., and R. Lasek (1989) Transport of cytoskeletal elements form parent axons into regenerating and daughter axons. J. Neurosci. 9: 436-446.

McQuarrie, I. G., S. T. Brady, and R. J. Lasek (1986) Diversity in the axonal transport of structural proteins: Major differences between optic and spinal axons in the rat. J. Neurosci. 6: 1593-1605.

Miller, F. D., W. Tetzlaff, M. A. Bisby, J. W. Fawcett, and R. J. Milner (1989) Rapid induction of the major embryonic $\alpha$-tubulin mRNA T $\alpha 1$, during nerve regeneration in adult rats. J. Neurosci. 9: 14521463.

Mori, H., Y. Komiya, and M. Kurokawa (1979) Slowly migrating axonal polypeptides. Inequalities in their rate and amount of transport between two branches of bifurcating axons. J. Cell Biol. 82: 179-184.

Nixon, R. A., and K. B. Logvinenko (1986) Multiple fates of newly synthesized neurofilament proteins: Evidence for a stationary neurofilament network distributed nonuniformly along axons of retinal ganglion cell neurons. J. Cell Biol. 102: 647-659.

Oblinger, M. M., S. T. Brady, I. G. McQuarrie, and R. J. Lasek (1987) Cytotypic differences in the protein composition of the axonally transported cytoskeleton in mammalian neurons. J. Neurosci. 7: 453-462.

Pachter, J. S., and R. K. H. Liem (1984) The differential appearance of neurofilament triplet polypeptides in the developing rat optic nerve. Dev. Biol. 103: 200-210.

Schaffner, W., and C. Weissmann (1973) A rapid, sensitivc, and spccific method for the determination of protein in dilute solution. Anal Biochem. 56: 502-514.

Schoenfeld, T. A., L. McKerracher, R. Obar, and R. Vallee (1989) MAP $1 \mathrm{~A}$ and MAP $1 \mathrm{~B}$ are structurally related microtubule-associated proteins with distinct developmental patterns in the CNS. J. Neurosci. 9: $1712-1730$.

Sinicropi, D. V., and D. L. Mcllwain (1983) Changes in the amounts of cytoskeletal proteins within the perikarya and axons of regenerating frog motoneurons. J. Cell Biol. 96: 240-247.

So, K.-F., and A. J. Aguayo (1985) Lengthy regrowth of cut axons from ganglion cells after peripheral nerve transplantation into the retina of adult rats. Brain Res. 328: 349-354.

Tashiro, T., M. Kurokawa, and Y. Komiya (1984) Two populations of axonally transported tubulin differentiated by thcir intcractions with neurofilaments. J. Neurochem. 43: 1220-1225.

Tetzlaff, W., M. A. Bisby, and G. W. Kreutzberg (1988) Changes in cytoskeletal proteins in the rat facial nucleus following axotomy. $\mathbf{J}$. Neurosci. 8: 3181-3189.

Trecarten, M. J., M. P. Villegas-Pérez, M. Vidal-Sanz, S. Thanos, and A. J. Aguayo (1986) Growth of axons along peripheral nerve system grafts inserted into the retina of adult rats. Soc. Neurosci. Abstr. 12: 701 .

Vidal-Sanz, M., G. M. Bray, M. P. Villegas-Pérez, S. Thanos, A. J. Aguayo (1987) Axonal regeneration and synapse formation in the superior colliculus by retinal ganglion cells in the adult rat. J. Neurosci. 7: 2894-2907.

Villegas-Pérez, M. P., M. Vidal-Sanz, G. M. Bray, and A. J. Aguayo (1988) Influences of peripheral nerve grafts on the survival and rcgrowth of axotomized retinal ganglion cells in adult rats. J, Neurosci. $8: 265-280$.

Willard, M., and C. Simon (1983) Modulations of neurofilament axonal transport during the development of rabbit retinal ganglion cells. Cell 35: 551-559.

Wujek, J. R., and R. J. Lasek (1983) Correlation of axonal regeneration and slow component $B$ in two branches of a single axon. J. Neurosci. 3: $243-251$. 